\title{
Influence of treated mud on free shrinkage and cracking tendency of self-compacting concrete equivalent mortars
}

\author{
F. Taieb ${ }^{\mathrm{a}} \bowtie$, N. Belas ${ }^{\mathrm{a}}$, H.A. Mesbah ${ }^{\mathrm{b}}$ \\ a. Laboratory of Construction, Transportation and Environmental Protection, Department of Civil Engineering and Architecture, \\ University of Mostaganem, (Mostaganem, Algeria) \\ b. University Institute of Technology, Rennes, Materials and Thermo, Rheology (MTRHEO) at the Laboratory of \\ Civil and Mechanical Engineering Laboratory (LGCGM), University of Rennes 1 and \\ National Institute of Applied Sciences of Rennes, (Rennes, France) \\ $\triangle$ tayebfatima038@gmail.com
}

Received 6 March 2018

Accepted 1 October 2018

Available on line 4 April 2019

\begin{abstract}
The present work aims at studying the formulation and characterization of self-compacting concrete equivalent mortars, using calcined mud from the dredged sediments brought from the dam (Western Algeria) and fly ash from the Central Thermal EDF (France). Three SCCEM samples were prepared; a control mortar sample and two mortar samples containing $22 \%$ of mineral additions, with a ratio $\mathrm{W} / \mathrm{B}=0.47$. The analysis of the experimental results obtained indicates that mortars comprising calcined mud develop greater compressive strengths than those containing fly ash. Regarding free shrinkage, mortar with calcined mud is characterized by an autogenous shrinkage similar to those of control and fly ash mortars. However, it is more sensitive to total shrinkage and drying as compared to the other mortars. Under the conditions of restrained shrinkage, control and calcined mud mortars are more sensitive to early cracking than mortar based on fly ash.
\end{abstract}

KEYWORDS: Calcined mud; Fly ash; SCCEM; Free shrinkage; Cracking

Citation/Citar como: Taieb, F.; Belas, N.; Mesbah, H.A. (2019) Influence of treated mud on free shrinkage and cracking tendency of self-compacting concrete equivalent mortars. Mater. Construcc. 69 [334], e186. https://doi.org/10.3989/ mc.2019.02318

RESUMEN: Influencia del lodo tratado en la retracción libre y en la tendencia a la fisuración de morteros equivalentes de hormigón autocompactante. El presente trabajo tiene como objetivo estudiar la formulación y caracterización del morteros equivalentes de hormigón autocompactante, que utilizan lodo calcinado de los sedimentos dragados traídos de una presa (oeste de Argelia) y cenizas volantes del (EDF Central térmica, Francia). Se prepararon tres muestras de MEHA ; una muestra de mortero de control y dos muestras de mortero que contienen $22 \%$ de adiciones de minerales, con una relación a/s $=0.47$. El análisis de los resultados experimentales obtenidos indica que los morteros que contienen lodo calcinado desarrollan mayores resistencias a la compresión que los que contienen cenizas volantes. En cuanto a la retracción libre, el mortero con el lodo calcinado se caracteriza por una retracción autógena similar a los de los morteros de control y de cenizas volantes. Sin embargo, es más sensible a la retracción total y al secado en comparación con los otros morteros. En las condiciones de retracción restringida, los morteros de control y de base de lodo calcinado son más sensibles a la fisuración temprana que el mortero a base de cenizas volantes.

PALABRAS CLAVE : Lodo calcinado ; Ceniza volante ; MEHA ; Contracción libre ; Agrietamiento

ORCID ID: F. Taieb (https://orcid.org/0000-0001-7048-6489); N. Belas (https://orcid.org/0000-0003-0102-7937); H.A. Mesbah (https://orcid.org/0000-0003-1705-4681)

Copyright: (C) 2019 CSIC. This is an open-access article distributed under the terms of the Creative Commons Attribution 4.0 International (CC BY 4.0) License. 


\section{INTRODUCTION}

The siltation phenomenon of dams in Algeria has significantly increased in recent times. This has greatly reduced their storing capacity (significant decrease in the volume of water stored). Today, desilting is an effective technique to get rid of sediments from the bottom of dams. However, the deposition and storage of these sediments is a serious and costly problem (1). In order to answer to important request of construction materials used in the composition of cementitious materials, it becomes necessary to find new sources of materials as calcined mud from dredged sediments. Indeed, today it has become urgent and necessary to find new alternative materials that are cheaper than cement. In recent years, many researchers have been interested in the mud (sediment) from Oued Chorfa watershed which is well known for its high siltation rate $\left(675000 \mathrm{~m}^{3}\right.$ in 2015 , as released by the National Agency of Dams) (2).

The valorization of sediments from dams has both an environmental and economic objective, it represents an interesting alternative solution to dumping sediments (mud and silt) in nature on the one hand. On the other hand, it is advantageous to use calcined mud as a cement substitute in the preparation of concrete, because today cement manufacturing is quite costly and considerably polluting, since considerable amounts of carbon dioxide $\mathrm{CO}_{2}$ are released in the atmosphere. The search for a cheaper binder can be beneficial because nowadays cement is expensive and sometimes unavailable (3).

Concrete shrinkage can be defined as the deformation of a concrete element that is not subjected to any external mechanical stress in a constant thermodynamic environment (4). Indeed, deformations can be responsible for cracking, losses in prestressing, redistribution of stress, and sometimes, but more rarely, damage to the structure (5).

Several studies have been carried out, in recent years, on the effect of mineral additions, such as fly ash, silica fumes, blast furnace slag, calcareous filler, metakaolin, natural pozzolan and artificial pozzolan (calcined mud) on shrinkage in mortars and concretes (6-15). In general, incorporation of mineral additions in the formulation of mortar and concrete results in additional water demand, higher paste volume, and formation of additional C-S-H products, resulting in significant shrinkage (4). Similarly, the presence of additions is accompanied by a change in the microstructure and an increase in the percentage of finer capillary pores in hardened mortar and concrete, which may also lead to greater shrinkage $(16,17)$. However, smaller pores also reduce the diffusion rate and lead to less drying shrinkage (18), less total shrinkage, and smaller crack opening, which certainly increases the durability of concrete (19).

Based on studies conducted on the effect of mineral additions on self-compacting concrete shrinkage, it is possible to classify research works into two groups; a first group involving the majority of authors (20-26) who indicate that the shrinkage of SCCs, whether autogenous or in drying mode, is of the same order of magnitude, or even a little higher, but with smaller deviations, than those of vibrated concrete of the same class of strength. On the other hand, a second group of researchers observed more significant differences (27-29), with values that can be up to $20 \%$ higher in the case of SCCs (30). Though the measurement methods used are precise and accurate, the test conditions are most likely to play an important role in the variation of results; the formulation criteria may explain the obtained shrinkages, which may sometimes be similar or even larger (31).

Cracking is a complex phenomenon. Therefore, it would be interesting to emphasize that the risk of cracking depends not only on the extent and rate of shrinkage but also on other material properties, such as the modulus of elasticity, creep, flexural strength and fracture resistance (32). As reported by Hammer 2003 (33), all these properties must be taken into account in shrinkage in order to evaluate the cracking potential of SCCs (34). Indeed, Samouh 2015 (35) indicated that the sensitivity to cracking also depends among other the rate of impediment and the relaxation of the constraints $(36,37)$. The valorization of the materials extracted during the dredging of the silted dams was the object of our research, with the essential aim of not considering them as waste, but rather like raw material as synthesis pozzolan, that's why, it is imperative to study and identify the effects of treated sediments on the fresh and hardened properties of self-compacting concrete equivalent mortars.

The present work is devoted to the study of the influence of Chorfa dam mud compared to that of fly ash on the mechanical properties (compressive and flexural), free shrinkage, crack development due to restrained shrinkage, using ring tests, porosity accessible to water and bound and free water content of self-compacting concrete equivalent mortars. The study was conducted at the Laboratory of Civil and Mechanical Engineering Laboratory (LGCGM) of the University Institute of Technology of Rennes, and at the National Institute of Applied Sciences of Rennes (France).

\section{EXPERIMENTAL PROGRAM}

All tests were carried out under hygrothermic conditions, at a temperature of $20{ }^{\circ} \mathrm{C} \pm 1^{\circ} \mathrm{C}$ and $50 \% \pm 2 \%$ relative humidity 


\subsection{Materials}

\subsubsection{Cement}

The cement CEM I 52.5N-SR5 used for the different mortar formulations in accordance with the requirements of the NF EN 197-1 standard was from the Lafarge cement plant (France). It had a Blaine surface of $3800 \mathrm{~cm}^{2} / \mathrm{g}$ (38) according to the standard EN196-6 and an absolute density of $3.13 \mathrm{~g} / \mathrm{cm}^{3}(38)$ according to the standard NFP18555. The mineralogical composition of the clinker used is presented in Table 1.

TABle 1. Mineralogical composition of clinker (38).

\begin{tabular}{lcccc}
\hline Minerals & $\mathbf{C}_{3} \mathbf{S}$ & $\mathbf{C}_{2} \mathbf{S}$ & $\mathbf{C}_{3} \mathbf{A}$ & $\mathbf{C}_{\mathbf{4}} \mathbf{A F}$ \\
\hline$\%$ & 62 & 22 & 8 & 8
\end{tabular}

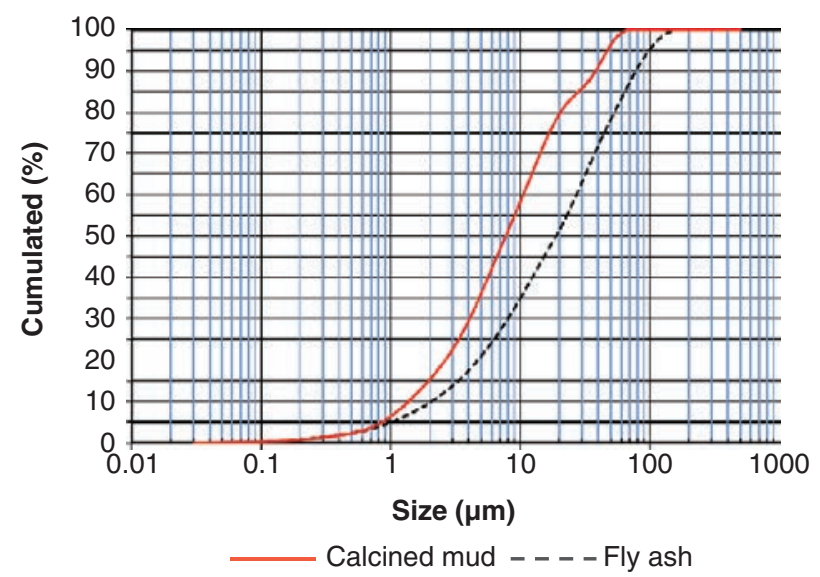

FIGURE 1. Laser granulometry of calcined mud and Fly ash.

TABLE 2. Physical characteristics of the calcined mud.

\begin{tabular}{llc}
\hline Tests & $\begin{array}{l}\text { Standards } \\
\text { used }\end{array}$ & $\begin{array}{c}\text { Results } \\
\text { obtained }\end{array}$ \\
\hline Fineness (Blaine) $\left(\mathrm{cm}^{2} / \mathrm{g}\right)$ & EN196-6 & 8310 \\
Specific gravity $\left(\mathrm{g} / \mathrm{cm}^{3}\right)$ & NFP18-555 & 2.65 \\
Pozzolanic activity index i ${ }_{28}$ & NFP 18-506 & 0.93 \\
\hline
\end{tabular}

\subsubsection{Mineral additions}

We used in our study two types of additions: the calcined mud and fly ash. The results obtained by the laser granulometry technique of these additions are shown in Figure 1.

The laser granulometry analysis was carried out using the CILAS 1180 granulometer. The samples were also subjected to wet analysis. The granular distribution of the grains of the calcined mud showed a higher proportion of the fine particles compared to the fly ash. It can clearly be noted that the proportion of $95 \%$ of the particles of the calcined mud was less than 50 microns in comparison with $75 \%$ for the fly ash, which confirms the great fineness of treated mud.

\subsubsection{Mud}

The mud used in the formulation of self-compacting concrete was brought from Chorfa Dam, which is located in the province of Mascara, in western Algeria. It was first dried in an oven at a temperature of $50{ }^{\circ} \mathrm{C}$; then, it was crushed and passed through an $80 \mu \mathrm{m}$, and after that it was subjected to heat treatment by calcination. To avoid thermal shock, the baking rate was set at 5 degrees per minute. The temperature was then kept constant $\left(750^{\circ} \mathrm{C}\right)$ for 5 hours (39). The product thus obtained (calcined mud) was then kept away from air and moisture (39). The physical characteristics of this mud are given in Table 2.

Additional analyses, aimed at identifying the calcined mud, were conducted by Scanning Electron Microscopy (SEM) and Energy Dispersive X-ray Spectroscopy (EDS). The spectra of the microanalysis indicated the presence of several chemical elements (Table 3 and Figure 2). The images obtained by Scanning Electron Microscopy showed irregular shapes of quartz grains of different sizes, ranging between $1 \mu \mathrm{m}$ and $6 \mu \mathrm{m}$, in the calcined mud.

\subsubsection{Fly ash}

The fly ash used in the formulation of the selfcompacting concrete equivalent mortar came from the Central Thermal EDF to Cordemais (France), it was a silico-aluminous "Class F" fly ash (38). The physical and chemical characteristics by $\mathrm{X}$-ray fluorescence of this fly ash are summarized in Tables 4 and 5 respectively (38).

TABLE 3. Chemical elements in calcined mud.

\begin{tabular}{lccccccccc}
\hline Element & $\mathbf{C}$ & $\mathbf{O}$ & $\mathbf{M g}$ & $\mathbf{A l}$ & $\mathbf{S i}$ & $\mathbf{K}$ & $\mathbf{C a}$ & $\mathbf{T i}$ & $\mathbf{F e}$ \\
\hline Mass $\%$ & 9.69 & 44.74 & 1.19 & 6.66 & 16.77 & 1.91 & 13.09 & 0.67 & 5.27 \\
Atomic $\%$ & 16.21 & 56.15 & 0.98 & 4.95 & 11.99 & 0.98 & 6.56 & 0.28 & 1.90 \\
\hline
\end{tabular}



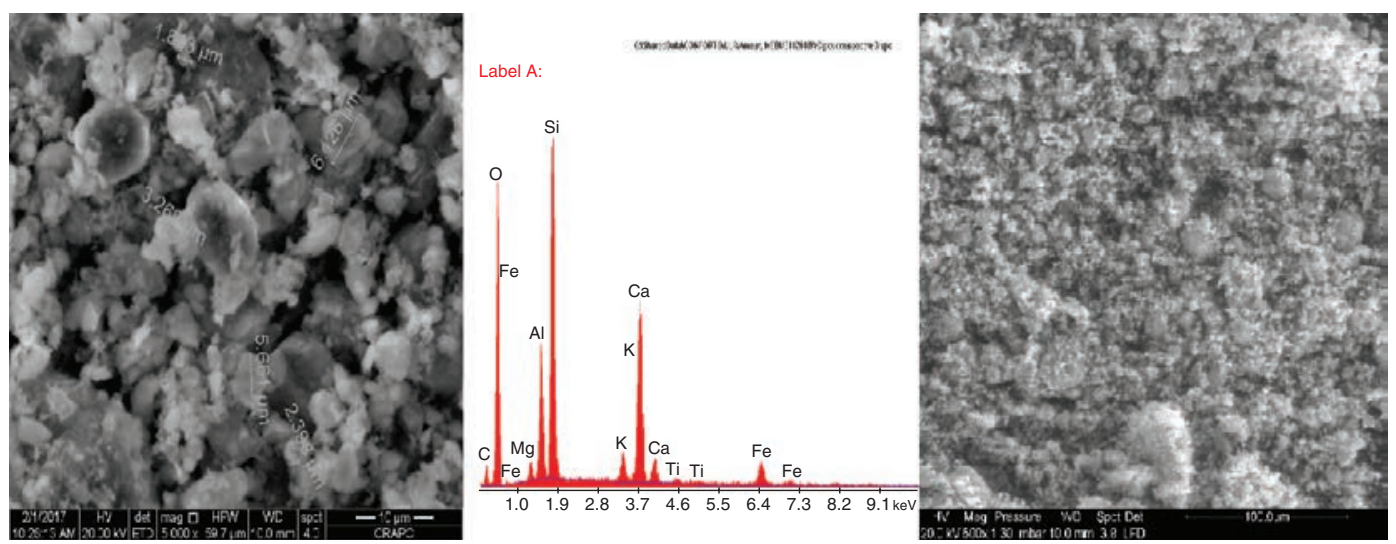

FIGURE 2. SEM and EDS analysis of calcined mud.

TABLE 4. Physical characteristics of Fly ash (38).

\begin{tabular}{llc}
\hline Tests & Standards used & Results obtained \\
\hline Fineness (Blaine) $\left(\mathrm{cm}^{2} / \mathrm{g}\right)$ & EN196-6 & 4334 \\
Specific gravity $\left(\mathrm{g} / \mathrm{cm}^{3}\right)$ & NFP18-555 & 2.05 \\
Pozzolanic activity index $\mathrm{i}_{28}$ & NFP 18-506 & 0.79 \\
\hline
\end{tabular}

TABle 5. Chemical composition of fly ash (38).

\begin{tabular}{lccccccccc}
\hline Oxides & $\mathrm{SiO}_{2}$ & $\mathrm{CaCO}_{3}$ & $\mathbf{C a O}$ & $\mathbf{F e}_{2} \mathbf{O}_{3}$ & $\mathbf{A l}_{2} \mathbf{O}_{3}$ & $\mathbf{M g O}$ & $\mathbf{N a}_{2} \mathbf{O}$ & $\mathbf{S O}_{3}$ & $\mathbf{H C L}$ \\
\hline Content $(\%)$ & 49.6 & - & 3.0 & 17 & 23.8 & 1.3 & 0.6 & 0.1 & - \\
\hline
\end{tabular}

TABlE 6. Composition of SCCEMs.

\begin{tabular}{lccccccc}
\hline Designation SCCEM (g/l) & W/B & Cement & Mud & Fly ash & Water & Admixture & S (0/4) \\
\hline SCCEM C & 0.47 & 649 & - & - & 304 & 1.5 & 1277 \\
SCCEM CM & 0.47 & 500 & 143 & - & 299 & 4.5 & 1266 \\
SCCEM FA & 0.47 & 494 & - & 141 & 295 & 1.5 & 1250 \\
\hline
\end{tabular}

\subsubsection{Sand}

An alluvial siliceous sand was used, of particle size 0/4, from the quarry of La Repennelais (France), with a density of $2.58 \mathrm{~g} / \mathrm{cm}^{3}$ (NFP 18-555) and a water absorption coefficient of $1.2 \%$ (38) follows normative rules NF P 18-554.

\subsubsection{Admixture}

A superplasticizer Sika Viscocrete Tempo 11 was used, of a new generation multi-purpose water reducer based on acrylic copolymer, with a density of $1.06 \pm$ 0.01 and a solid content between 28.5 and $31.5 \%$.

\subsection{Formulations of self-compacting concrete equivalent mortars (SCCEM)}

Considering the different data on the materials used, we derived three compositions of SCCEM from one composition of Self -Compacting Concrete containing fly ash (SCC5) formulated by Mesbah (40), a control mortar sample and two mortar samples containing the same percentage $(22 \%)$ of mineral additions. The preparation of the binder consisted of replacing $22 \%$ of the mass of the cement with the calcined mud and fly ash respectively, with a ratio $\mathrm{W} / \mathrm{B}=0.47$. Their compositions are given in Table 6. 
where:

SCCEMC: Control self-compacting concrete equivalent mortar

SCCEM CM: self-compacting concrete equivalent mortar containing calcined mud

SCCEM FA: self-compacting concrete equivalent mortar containing fly ash.

\subsection{Tests on SCCEM fresh}

\subsubsection{The Slump flow}

As an integral part of a SCC, self-compacting mortars (SCEMs) may serve as a basis for the design of concrete since the measurement of the rheological properties of SCCs (41). According to the procedure recommended by EFNARC committee (European Federation for Specialist Construction Chemicals and Concrete Systems) (42), the measure technique helped to characterize rheological properties of SCCEM. All mortar mixtures were designed to give a slump flow diameter of $20 \pm 1 \mathrm{~cm}$ instead of $25 \pm 1 \mathrm{~cm}$ to avoid bleeding and segregation. In the production of SCEMs, the mixing process was kept constant to supply the same homogeneity and uniformity in all mixtures (41).

After leaving the cone, the final diameter reached by the slump flow slab is measured.

\subsubsection{Setting time}

The initial and final setting times of the self-compacting concrete equivalent mortars prepared were measured using a classical automatic VICAT apparatus, according to standard NF EN 480-2.

\subsection{Tests on SCCEM hardened}

\subsubsection{Testing the mechanical behavior}

The tests were carried out on prismatic specimens of dimensions $4 \times 4 \times 16 \mathrm{~cm}^{3}$, previously preserved in water as soon as they were demolded, until the crushing deadline (28 days) in order to determine the flexural (tensile) strength, using the three-point bending test, and the compressive strength according to the standard EN 196-1.

\subsubsection{Thermal measurement of free and bound water content}

The main objective of the thermal analysis was to follow the evolution of bound and free water content of the binder pastes. The compositions of these pastes are given in Table 7. It is worth reminding that bound water can be considered as an important and reliable indicator of hydration progress and microstructure modification (43). A crushed sample, with particle size less than $2.5 \mathrm{~mm}$ (about $4 \mathrm{~g}$ ), was placed
TABLE 7. Formulations of binder pastes.

\begin{tabular}{lccc}
\hline $\begin{array}{l}\text { Identification } \\
\text { of Pastes (g/l) }\end{array}$ & $\begin{array}{c}\text { PC (Control } \\
\text { paste) }\end{array}$ & $\begin{array}{c}\text { PCM (Paste } \\
\text { containing } \\
\text { calcined mud) }\end{array}$ & $\begin{array}{c}\text { PFA(Paste } \\
\text { containing } \\
\text { fly ash) }\end{array}$ \\
\hline Cement & 649 & 500 & 494 \\
Calcined mud & - & 143 & - \\
Fly ash & - & - & 141 \\
Water & 304 & 299 & 295 \\
W/B & 0.47 & 0.47 & 0.47 \\
\hline
\end{tabular}

in a calcined and tared crucible. Let $\mathrm{M}_{\mathrm{i}}$ be the initial mass of the paste. The crucible was then introduced into the oven at the temperature of $80^{\circ} \mathrm{C}$ to dry the sample. Each weighing was carried out after allowing the crucible, holding the paste, to cool down for 15 minutes inside a desiccator containing silica gel. Let $\mathrm{M}_{80}{ }^{\circ} \mathrm{C}$ be the final dry mass of paste (44). The relative mass loss corresponding to free water is then given by [1]:

$$
\Delta \mathrm{M}_{\text {free water }}=\left(\mathrm{M}_{\mathrm{i}}-\mathrm{M}_{80^{\circ} \mathrm{C}}\right) / \mathrm{M}_{\mathrm{i}}(44)
$$

After that, the crucible containing the dry ground matter was introduced into the oven at $105^{\circ} \mathrm{C}$, for 2 hours; then, it was allowed to cool for 15 minutes inside a desiccator containing silica gel; next, it was weighed. The operation was repeated, but with the oven temperature set first at $400{ }^{\circ} \mathrm{C}$ and then at $600{ }^{\circ} \mathrm{C}$, for 1 hour, for the two temperatures. The relative loss of mass at $600{ }^{\circ} \mathrm{C}$ is then given by [2]:

$$
\Delta \mathrm{M}_{\text {hydration water }}=\left(\mathrm{M}_{80^{\circ} \mathrm{C}}-\mathrm{M}_{600^{\circ} \mathrm{C}}\right) / \mathrm{M}_{80^{\circ} \mathrm{C}}(44)
$$

The operation was repeated in the oven where the temperature was previously set at $1000{ }^{\circ} \mathrm{C}$. The relative loss of mass between $600{ }^{\circ} \mathrm{C}$ and $1000^{\circ} \mathrm{C}$ is therefore equal to [3]:

$$
\Delta \mathrm{M}_{\mathrm{CO} 2 \text { of carbonates }}=\left(\mathrm{M}_{600}{ }^{\circ} \mathrm{C}-\mathrm{M}_{1000}{ }^{\circ} \mathrm{C}\right) / \mathrm{M}_{80}{ }^{\circ} \mathrm{C} \text { (44) [3] }
$$

\subsubsection{Porosity accessible to water}

This test consisted of measuring the percentage of voids, inside the mortar mass, which are connected to the surface, in accordance with standard NF P 18-459. Porosity is measured on prismatic specimens of dimensions $4 \times 4 \times 16 \mathrm{~cm}^{3}$, at 28 days. The porosity accessible to water, $\varepsilon$, which is expressed as a percentage of the volume, is given by the following relation [4]:

$$
\varepsilon=\frac{\text { M AIR }- \text { M DRY }}{\text { M AIR }- \text { M WATER }} \times 100
$$


Where:

$\mathbf{M}_{\text {water }}$ is the mass in grams of the half specimen immersed in water

$\mathrm{M}_{\mathrm{air}}$ is the mass in grams of the soaked half-specimen weighed in air

$\mathrm{M}_{\mathrm{dry}}$ : the mass in grams of the dry half-specimen

\subsubsection{Free shrinkage}

The present study was carried out on mortar samples of dimensions $4 \times 4 \times 16 \mathrm{~cm}^{3}$, in accordance with the French standard NF P 15-433. The autogenous shrinkage and total shrinkage measurements were carried out from 24 hours after the beginning of malaxation. The specimens used to investigate the autogenous shrinkage were fully coated with adhesive aluminum foil to prevent any water exchange with the outside environment. All test pieces were then stored in a room with a controlled atmosphere. The measurements were carried out using a micrometer comparator, at a rate that is adapted to the kinetics of the observed phenomena. The difference between the total shrinkage and autogenous shrinkage allows obtaining the drying shrinkage.

\subsubsection{Initiation and development of cracks by the restrained shrinkage test}

In order to study the early-age cracking tendency of SCCEMs, it was decided to carry out restrained shrinkage tests using ring tests (43), according to the standard ASTM C.1581(45). The approach consisting of casting a mortar ring next to a steel ring was used to simulate the restrained shrinkage cracking
(46). The test method involves casting a mortar ring around a steel ring. The geometry and testing device for specimens are described in Figure 3 (18). In this study, the upper surfaces of mortar rings were protected from desiccation by a double layer of aluminum adhesive, only the circumferential surface was exposed to drying (47). When the crack appeared on the surface of the mortar ring, its width was first measured using a microscope, then, a sensor was placed on the crack for measuring that same width. The evolution of the crack opening was recorded, every 15 minutes, over time.

\section{RESULTS AND ANALYSES}

\subsection{Fresh state}

The test results of self-compacting concrete equivalent mortars (SCCEMs) in the fresh state are given in Table 8.

\subsubsection{The Slump flow}

All mixtures of mortar were made to give slump flow diameter of $20 \pm 1 \mathrm{~cm}$ (avoiding segregation) which was acquired by adding the used admixture (41). The slump flow test results presented in table 6 and figure 4, show clearly that SCEMs present satisfying values, between 19.25 and $20 \mathrm{~cm}$. It was noticed that the use of calcinated vase increased slightly slump flow diameter of mixtures. In addition, it should be noted that all the mortars tested are located in relatively narrow ranges of values, given the uncertainties recognized for this test (48).
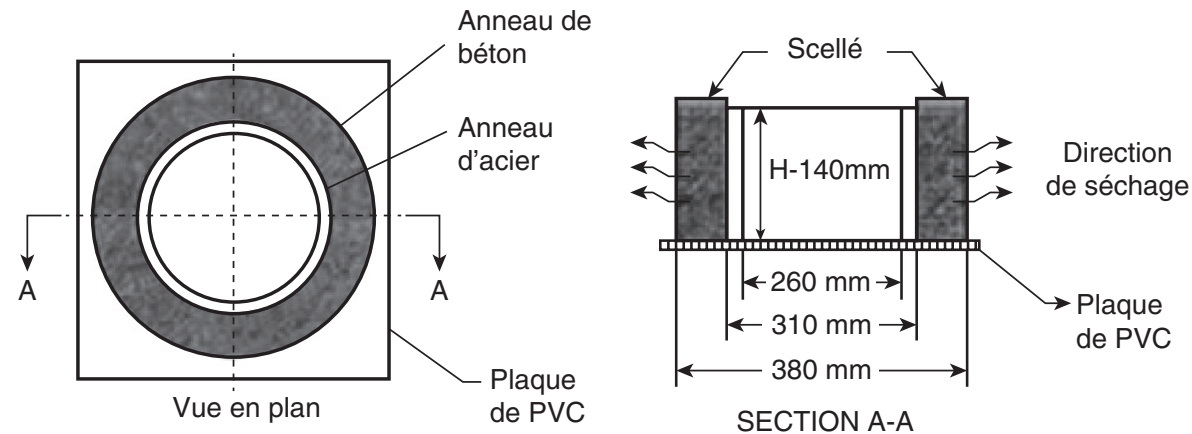

Figure 3. Geometry of the steel and concrete rings used in this study (18).

TABLE 8. Characterization of SCCEMs in the fresh state.

\begin{tabular}{lcccc}
\hline SCCEM & Slump flow $(\mathbf{c m}) \boldsymbol{\emptyset}$ & Initialsetting time (min) & Finalsetting time (min) & Settingtime (min) \\
\hline SCCEMC & 19.25 & 245 & 458 & 213 \\
SCCEMCM & 20 & 282 & 520 & 238 \\
SCCEMFA & 19.25 & 360 & 590 & 230 \\
\hline
\end{tabular}




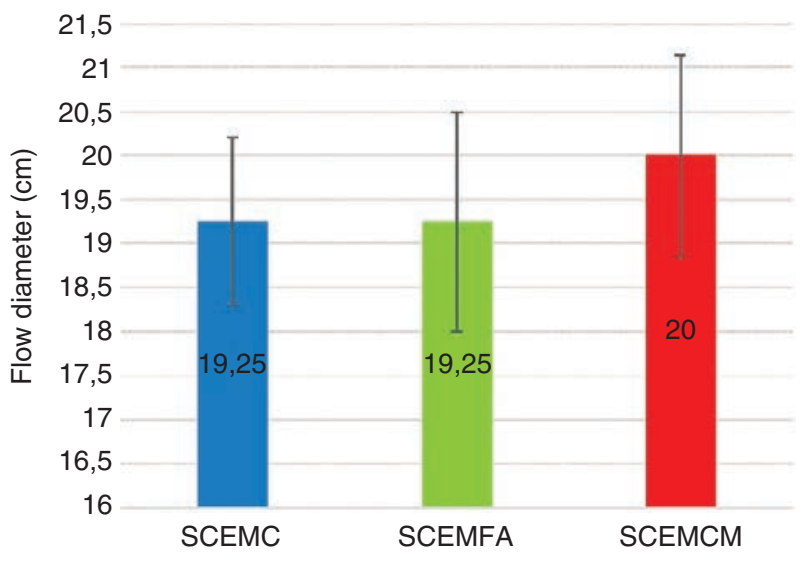

FIGURE 4. Slump flow variation of SCEMs studied.

\subsubsection{Setting time}

The measurement results of the setting times of the different concrete equivalent mortars are presented in Figure 5. It was easy to observe that the mineral additions (calcined mud and fly ash) had a very light effect on the setting times of the formulated mortars as compared with the SCEMC with a maximal gap of 25 minutes.

This may be explained by the fact that the fineness of the mixture, which is attributed rather to calcined mud $\left(8310 \mathrm{~cm}^{2} / \mathrm{g}\right)$ and fly ash $\left(4334 \mathrm{~cm}^{2} / \mathrm{g}\right)$ than to cement $\left(3800 \mathrm{~cm}^{2} / \mathrm{g}\right)$, allowed having a larger area of contact with water. In addition, the setting time increased is attributed to the low hydration heat of mortars containing additions, because of the lower clinker content. Indeed, Jian. S et al. (49) studied the effect of mineral additions, such as fly ash, silica fume and blast furnace slag, with different percentages, on the hydration heat of mortars. They found out that the endothermic hydration process of mortars was greatly influenced by the partial replacement of cement with one of these additions (50). Thus, the delay in setting times during introduction of the studied additions may be due to the low hydraulicity of the fly ash and calcined mud. It is also noted that the replacement of Portland cement with fly ash involved a delay in the initial and final setting time of the obtained mortar as compared to that of mortar containing calcined mud. The time delay can be attributed to several factors, such as the high fineness of calcined mud, higher superplasticizer content of SCEM CM as compared to that of SCEM FA, low hydration heat, and slow hydration kinetics of SCEMCM at young age.

\subsection{Hardened state}

\subsubsection{Compressive strengths}

The evolution of the compressive strength, at 28 days, as a function of the mineral additions is illustrated

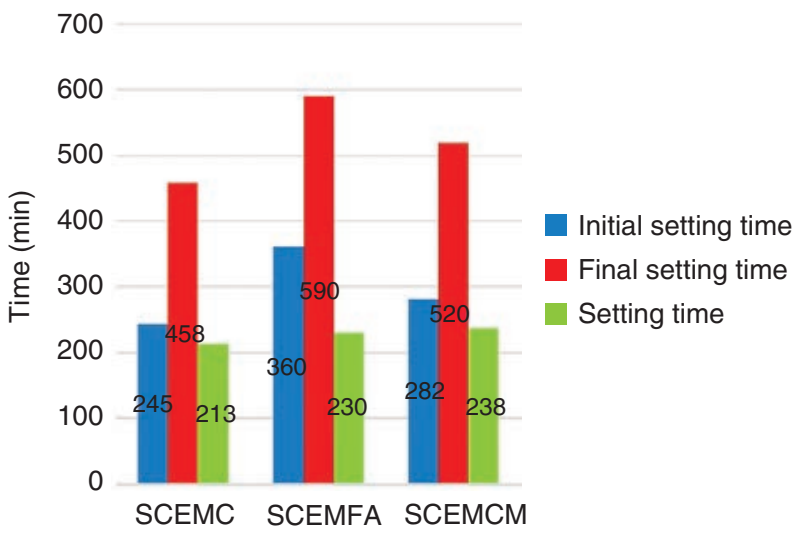

Figure 5. The initial times of setting, the final of setting and the setting time of SCEMs studied.

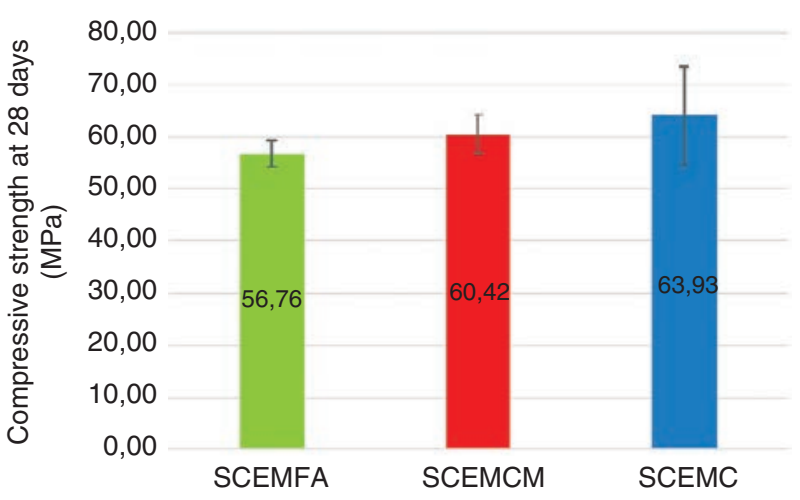

FIGURE 6. Evolution of the compressive strength at 28 days of SCEMs studied.

in Figure 6. According to the results obtained the SCEMC displayed better mechanical performances than those of SCEMCM and SCEMFA.

Depending on the nature of the addition, the calcined mud SCEM developed better strengths as compared to the fly ash SCEM. This can be explained by the physical effect of the calcined mud as a result of great finesse $\left(8310 \mathrm{~cm}^{2} / \mathrm{g}\right)$ compared to the fly ash $\left(4334 \mathrm{~cm}^{2} / \mathrm{g}\right)$. Indeed, Sabir and al 2001 have shown that finesse, the morphology of the particles is also an influential parameter on the intensity of the Pozzolanic activity (51). In addition, the activity index of the calcined mud was 0.93 at 28 days compared to 0.79 at 28 days of fly ash, which was a sign of a strong Pozzolanic activity.

In addition, this can also due to the latent property of hydration of cements containing fly ash (43). The kinetics of the development of strengths in SCEMCM may be explained by the activity of mud and by the fact that the pozzolanic action became sensitive from the early age, this action broke out and started fixing the lime released by cement during its hydration. As a result, the newly formed calcium silicate hydrates (CSHs) will contribute to strength (52). 


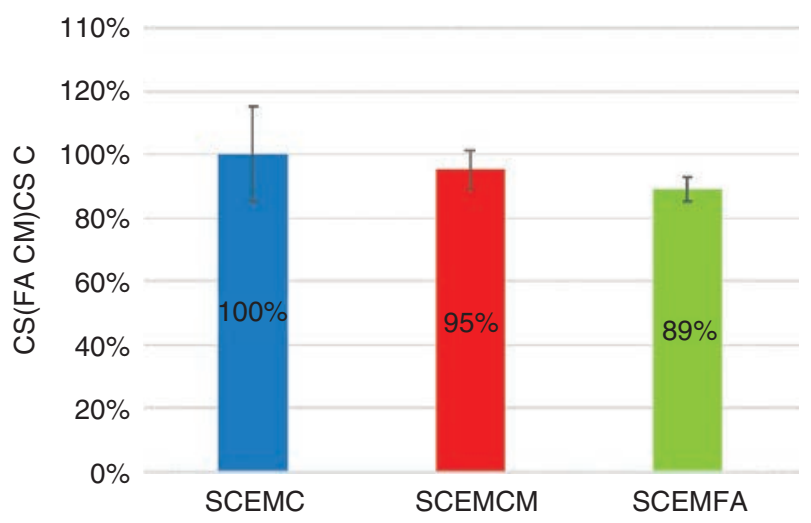

FIGURE 7. Evolution of the fraction of compressive strengths of SCEMs based on mineral additions compared to control SCEM.

For better visualizing the evolution of the compressive strength, we compared the various ratios of the SCEM containing the mineral additions (calcined mud and fly ash) with the SCEMC, as illustrated in Figure 7. This fraction was greater for calcined mud SCCEM than for fly ash SCCEM. At 28 days, the compression strengths of fly ash SCCEM and calcined mud SCCEM were smaller by $5 \%$ and $2 \%$, respectively, than that of control SCCEM.

\subsubsection{Flexural strength}

The 28-day flexural strengths were shown graphically in Figure 8. It is well known that the factors that affect the compressive strength evolution of mortars also influence their flexural strength evolution (14). However, this was not true for our mortars because calcined mud SCCEM had the smallest tensile strength value. Neville (1996) indicated that there was a direct proportionality between splitting tensile strength and compressive strength of the concrete strength (53). Nevertheless, the two flexural strengths of mortars with the two additions (calcined mud and fly ash) remain close to each other.

According to the results obtained, control SCCEM displays higher flexural strength than those of calcined mud SCCEM and fly ash SCCEM.

For better visualizing the evolution of the flexural strength, we compared the various ratios of the SCEM containing the mineral additions (calcined mud and fly ash) with the SCEMC, as shown in figure 9. The fraction of fly ash SCCEM was greater than that of calcined mud SCCEM. At 28 days, the flexural strengths of fly ash SCCEM and calcined mud SCCEM were smaller by $17 \%$ and $22 \%$, respectively, than that of control SCCEM.

\subsubsection{Bound and free water content}

Figures 10 display the results of measurements of the quantities of free water and bound water, for

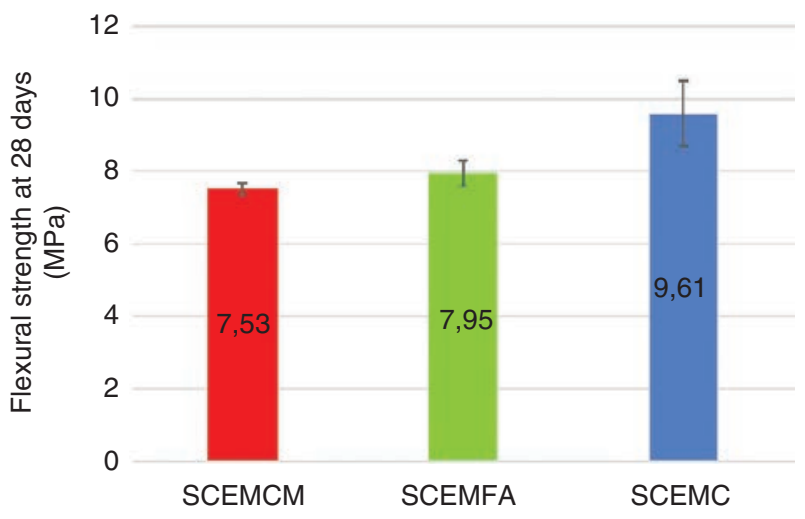

FIGURE 8. Evolution of flexural strengths of SCEMs, at 28 days

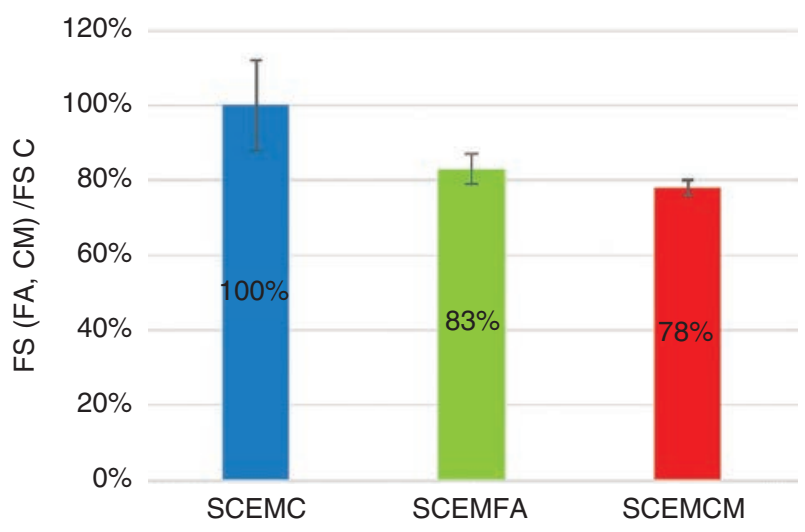

FIGURE 9. Evolution of the fraction of flexural strengths of SCEMs based on mineral additions compared to control SCEM.

the three cement pastes, after 28 days of dry cure. The results showed a lower bound water content for the mortar paste containing fly ash compared to calcined mud and reference paste, which indicated less hydration and therefore the likely development of a smaller amount of hydrates at young age, and so less compressive strength in comparison with the compressive strength of SCEMC and SCEMCM. The results obtained indicated that the bound water content was greater in paste containing calcined mud as compared to the other two. This means that hydration was more important, and therefore a larger amount of hydrates was very likely to develop. The binder containing calcined mud had the highest free water content; it was close to that of the control binder. These results were consistent with those relating to porosity accessible to water. Indeed, it was clearly noted that the porosity of control SCEM was lower, then came that of fly ash SCEM. The measured free water content allowed an estimation of the porosity of the mortars studied. This free water occupied part of the porous network (44), so the quantity of free water in each mortar depends on the porous structure of this mortar. 

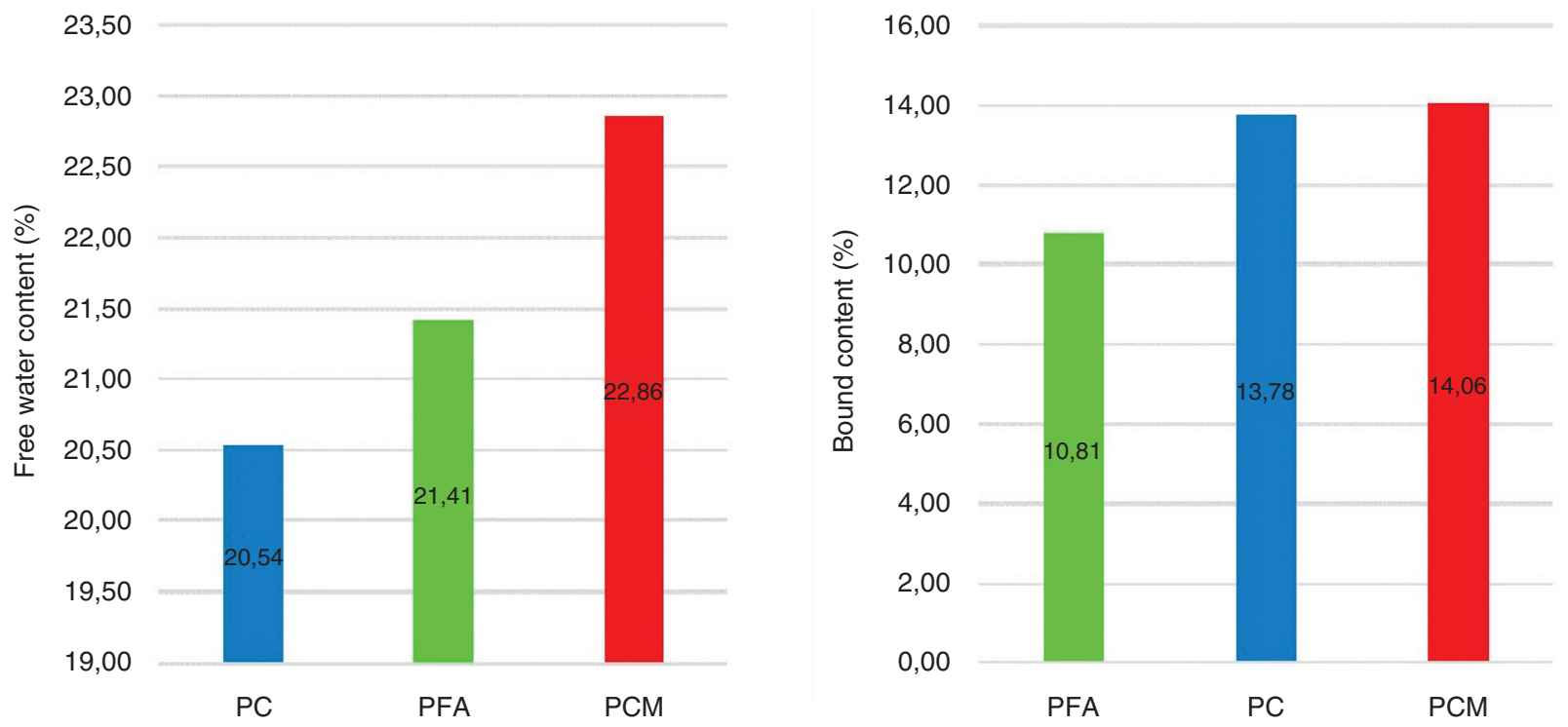

FIGURE 10. Free and bound water content of the mortar pastes studied.

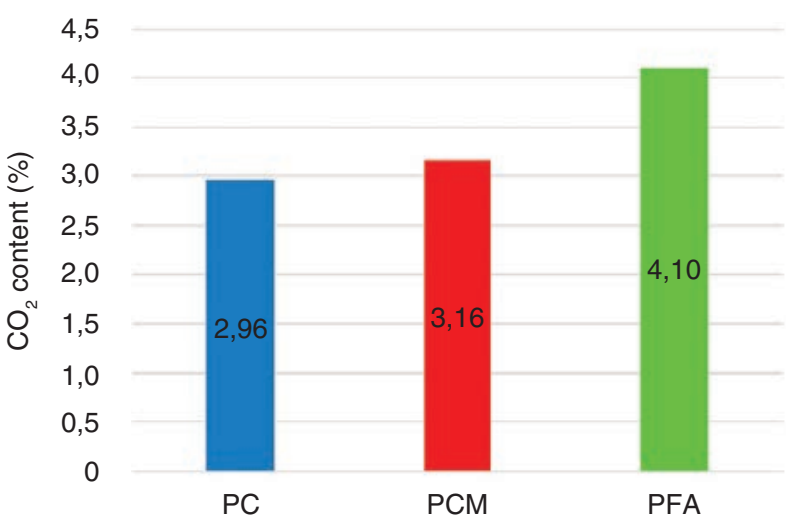

Figure 11. $\mathrm{CO}_{2}$ content of the mortar pastes studied.

Figure 11 showed the results for $\mathrm{CO}_{2}$ content in the three cement pastes, after 28 days of dry cure. These results indicated that the $\mathrm{CO}_{2}$ content was lower in the mixtures containing calcined mud than in those containing fly ash. The state of carbonation also plays a major role. In the case of Portland cement materials, carbonation caused a decrease in the diffusion coefficient which was well correlated with the decrease in porosity (54). In contrast, the $\mathrm{CO}_{2}$ content of fly ash paste increased while its porosity and bound water content decrease. The increase in carbonation for fly ash with less porosity compared to calcined mud may be related to differences in the porous structure. The use of fly ash gives a denser porous structure, but at the same time a portion of $\mathrm{Ca}(\mathrm{OH})_{2}$ was consumed by the hydration of fly ash, which lead to a high depth of penetration (38).

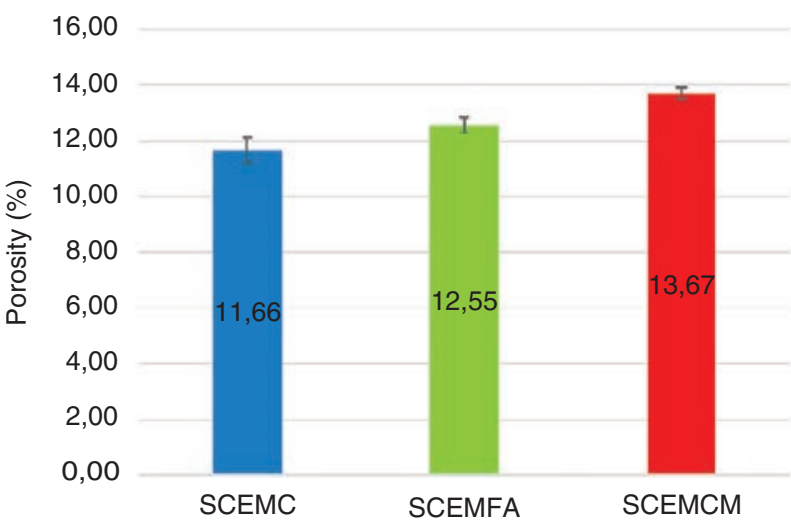

Figure 12. Porosity accessible to water of the different SCEMs studied.

The carbonation depth also depended on the nature of the addition, in particular the $\mathrm{CaO}$ content of the fly ash. The higher this content, the lower the carbonation depth (38). This can be explained by the low percentage of $\mathrm{CaO}(3 \%)$ in the fly ash compared to the calcined mud $(17 \%)$.

According to Audenaert et al. (2007), the incorporation of fly ash had no noticeable effect on improving the strength of SCCs to carbonation (55). Ongoing studies, such as capillary absorption and permeability may to corroborate these results.

\subsubsection{Porosity accessible to water}

Figure 12 showed the porosity results obtained for the three concrete equivalent mortars under study, after 28 days of dry cure. It can be seen that the porosity of concrete equivalent mortar containing 
fly ash was lower than that of calcined mud concrete equivalent mortar, and the accessible water porosity of fly ash SCEM is $8 \%$ higher than that of control SCEM. In addition, the use of calcined mud as a partial substitute for Portland cement lead to an increase in water porosity of $17.2 \%$, at 28 days, with respect to that of control SCEM. These results were in agreement with those relating to the free water content. Comparison between the results relating to the mortars studied allows concluding that the porosity accessible to water increases in mortars containing mineral additions as partial substitute for cement (38). This increase in porosity during the introduction of calcined mud and the fly-ash can be due to the least pozzolanicity and hydraulicity of these additions in short-term (28 days). In addition, the pozzolanicity or the hydraulicity of the fly-ash can reduce the porosity in long-term if the mortar is preserved wet (56).

\subsubsection{Free shrinkage}

3.2.5.1. Autogenous shrinkage: Autogenous shrinkage was a phenomenon that was specifically related to cement hydration, which testifies to its evolution and to the quantity of hydrates formed. This shrinkage increased rapidly as the amount of water decreases, it ended $(95 \%)$ after 1 to 4 weeks (5).

From Figure 13, two steps can be distinguished: during the first 20 days, the autogenous shrinkage of SCEMs evolves rapidly with time, from 20 to 100 days, the shrinkage evolution was stabilized. All mortars exhibited almost similar deformations, from the first days and for the entire period of the tests with a slight superiority for the SCECM. Because this shrinkage was attributed mainly to the
C-S-H content which would be relatively higher in the case of mixtures of Portland cement-pozzolan (57). This slight predominance in the presence of calcined mud may be attributed to the fact that the volume of hydrates formed was slightly lower than the total volume of the initial constituents (water + cement). Hydration causes a decreased in volume after mortar setting. It can thus be clearly stated that mortars containing calcined mud reveal the formation of additional hydrates than those due to the hydration of the cement. Indeed, the eventual pozzolanic reaction of calcined mud may well be the cause, without neglecting the physical effect of this same mud whose fineness was quite high. Thus, a filling effect was observed, which lead to a decrease in capillarity, and consequently favored the internal capillary tensile forces (15). In contrast, the fly ash mortar presented the lowest autogenous shrinkage, this may be attributed to lower hydration.

Based on the definition of SCEMs containing mineral additions and adjuvants, with proportions higher than those in ordinary mortars, it can be said that these two elements have an influence on the hydration of cement and on its consequences (58). The volume of hydrates formed is much smaller than the sum of the volumes of the two constituents, i.e. anhydrous cement and water, which participated in the chemical reaction (Le Chatelier contraction) (47). It was widely admitted that autogenous shrinkage is caused by the relative humidity changes that took place in pores (59). Various mechanisms can be triggered depending on the structure of pores and the available water (59).Autogenous shrinkage of SCEMFA showed a similar development, depending on the mechanical strengths. This had already been noted in the results relating to compression.

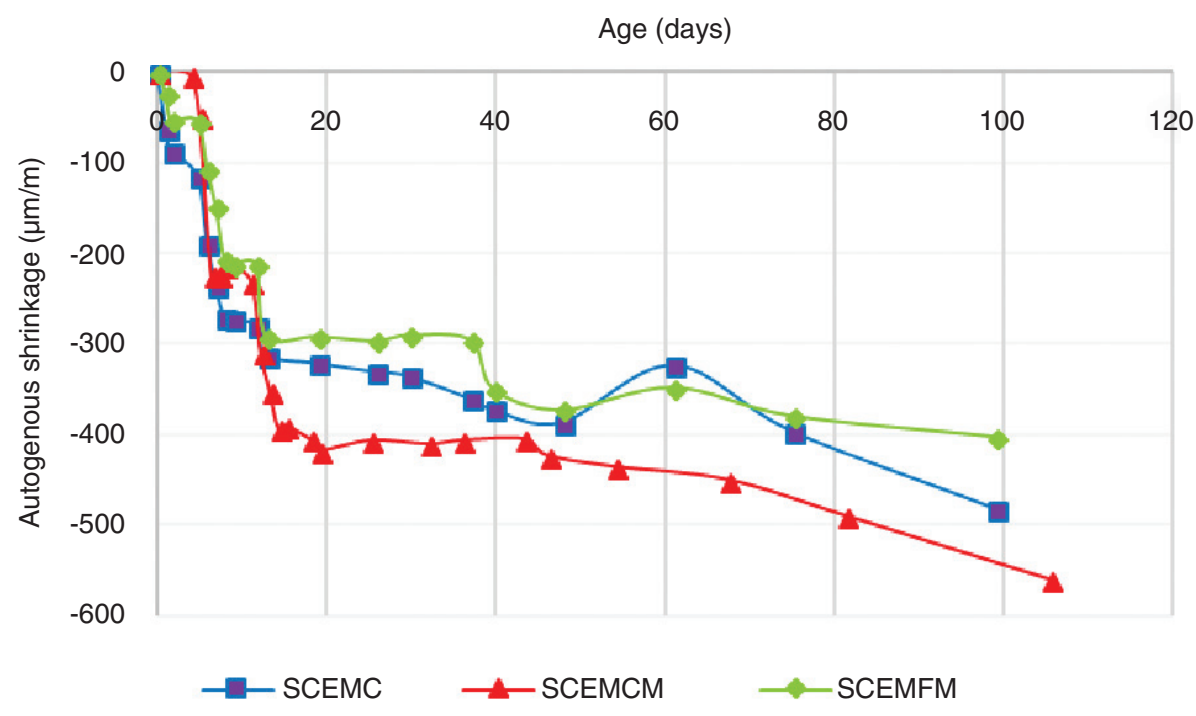

FIGURE 13. Evolution of autogenous shrinkage as a function of time. 
3.2.5.2. Total shrinkage: Hydration and water exchanges with the atmosphere caused shrinkage deformations on mortars, irrespectively of any external mechanical stress. Spontaneous variations due to the total shrinkage were due to changes in moisture content that was engendered by the hydration reactions and evaporation (52).

It can be seen from Figure 14 that the total shrinkage changed very rapidly, for all types of samples that were stored in the open air; this may be attributed to their size which was more favorable to desiccation (14). We observed a similar evolution of deformation, at young age (until the first 7 days), for all SCEMs, since at a very young age, it was difficult to distinguish between the graphs representing each mortar. However, after 7 days, the SCEMFA displayed the lowest total deformations starting from the first week and remained as such for the entire period of the tests. However, the shrinkages of SCEMC and SCEMCM grew within a very tight beam until the age of 12 days. After this period, the mortar containing calcined mud started to move away from the other mortars; it displayed the highest shrinkage values. This can be explained by what had previously been seen with the results on the crack tendency through the ring test where the calcined mud-based mortar was the first to crack, the control mortar was second and the fly ash-based mortar was last.

3.2.5.3. Drying shrinkage: The deformation of the specimens was due to the drying shrinkage when there was an exchange of water between them and the environment. The shrinkage values represented the combination of drying and carbonation which testify to the porosity of the microstructure and to its ability to promote drying (4).

Figure 15 showed that the SCEMFA had the lowest shrinkage values after the first week of hardening. On the other hand, the SCEMCM showed the highest shrinkage value as compared to control mortar and fly ash concrete equivalent mortar.

Regarding drying, it was noted that shrinkage depended on the amount of evaporable water within the cement paste (52). Therefore, calcined mudbased paste was characterized by high free water content and, consequently, greater drying shrinkage. The low desiccation shrinkage of fly ash-based mortar had been demonstrated and confirmed by Atiz et al. (60) who studied the evolution of shrinkage of mortar specimens with a ratio W/C equal to 0.4 . The results they obtained enabled them to conclude that the shrinkage of a mortar containing 10, 20 and $30 \%$ of fly ash decreased by 25,37 and $43 \%$, respectively, after 5 months of observation. This was certainly attributed to the high concentration of free lime $(\mathrm{CaO})$ and periclase $(\mathrm{MgO})$ in fly ash. Chindaprasirt et al. (61) examined the effect of fly ash fineness on deformation due to drying shrinkage; they obtained results that allow confirming that all fly ash mortars had a lower shrinkage, regardless of their fineness. This was probably due to the smaller amount of water needed in the presence of fly ashes. The American Concrete Institute (ACI) Committee 232 (62) indicated that the shrinkage of fly ash-based mortar increased slightly if the W/C ratio remained constant. The difference between the shrinkage values remains low for a substitution level lower than 20\%. Similarly, Mehta (63) confirmed

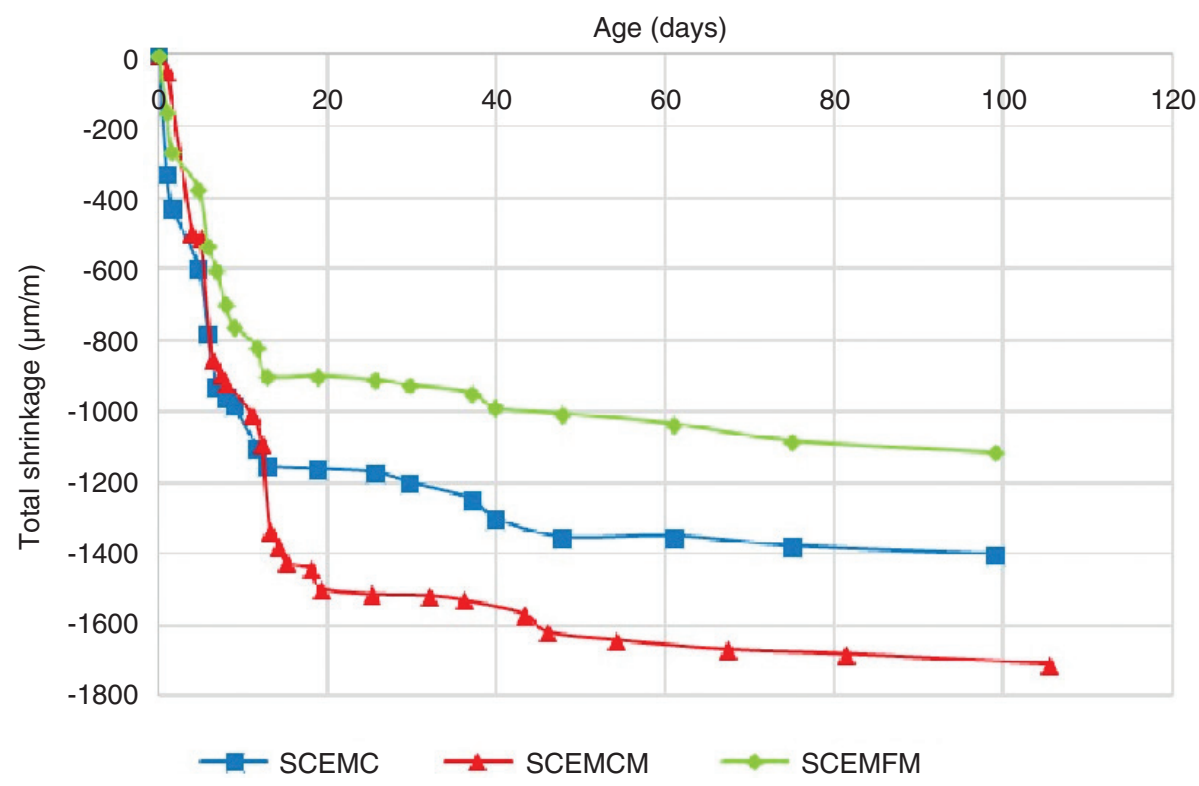

FIGURE 14. Evolution of total shrinkage as a function of time. 
that the shrinkage remained practically constant for concretes containing less than $25 \%$ of fly ash. Therefore, it can be said that the addition of fly ash limits the drying shrinkage of mortar.

\subsubsection{Initiation and development of cracks using the restrained shrinkage test}

The restrained shrinkage tests were performed during a 49-day period. The formwork removal took place 24 hours after the manufacture of the SCEMs. Figure 16 showed the evolution of crack widths.

Flexural stresses developed under the effect of the restrained shrinkage; cracks appear when these stresses exceed the flexural strength of the mortar (64).

When monitoring the restrained shrinkage using the ring test under desiccation conditions, the SCEM CM and SCEMC were the first to crack, as illustrated in Figure 16. The SCEMCM cracked first at 2.71 days after formwork removal, followed by SCEMC at 2.81 days, and by SCEMFA at the age of 3.98 days. From Figure 16, crack openings due to the restrained shrinkage are determined using a sensor. The results obtained clearly showed the age of the appearance of the crack as well as the evolution of its opening, for all the SCEMs under study. Cracks can occur when the flexural stress due to the restrained shrinkage created within mortar exceeds the flexural strength of the material (43). At early ages, this flexural strength increased steadily and the constraints were generated by volume changes (18). Improvement in flexural strength of the concrete provided resistance against shrinkage cracking (65).
The SCEM CM and SCEMC cracked earlier than the SCEMFA. However, the crack openings in the control concrete equivalent mortar were smaller than those in the mortars containing mineral additions. The SCEMC crack presented an aperture that was 1,2 and 1,3 times lower than those of SCEM FA and SCEM CM, respectively. This difference was certainly due to the low porosity of SCEMC. The differences between widths of cracks observed in this study should be related to the differences in the fracture energy, flexural strength, and stress developed in mortar rings at early age (43). The incorporation of $22 \%$ of fly ash in mortar delays the appearance of cracks. This result can be explained by the high flexural strengths and the low compressive strengths of SCEM FA in comparison with the SCEM CM. The flexural strength of the mortar containing the calcined mud clearly intervened in the sensitivity to cracking, where the SCEMCM underwent higher flexural stresses despite its higher compressive strength, it cracked the first, i.e. the stress increased with early crack. Also, one can refer to its higher drying shrinkage and its weak autogenous shrinkage, since drying shrinkage was one of the major parameters responsible for cracking (66).

The results relative to bound water content showed that there was an indirect correlation between the amount of bound water in mortar and the age of cracking. In fact, the increase in bound water lead to a decrease in the age of cracking, thus increasing the risk of cracking. In effect a normal consistency test was performed by the Vicat apparatus, on a paste of $100 \%$ of calcined mud was in normal consistency with a ratio water / mud of 0.45

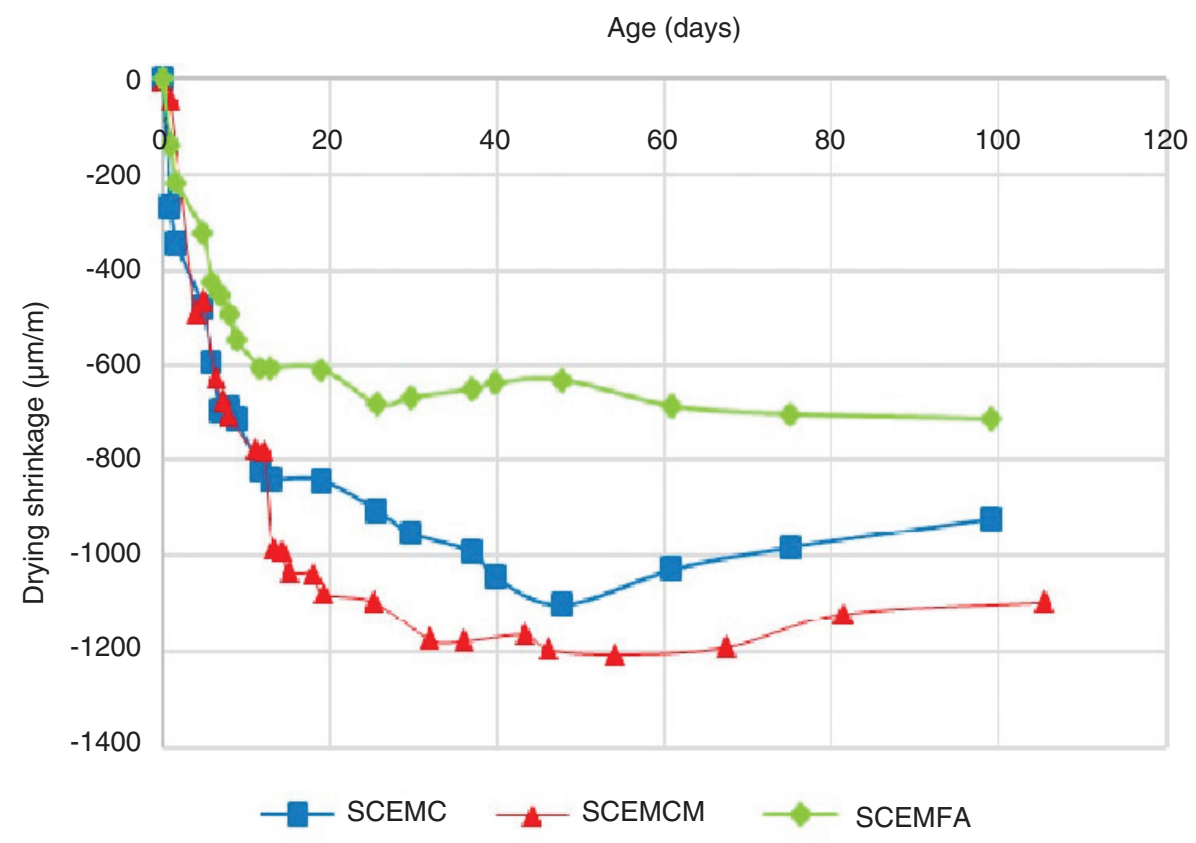

FIGURE 15. Evolution of drying shrinkage with time. 


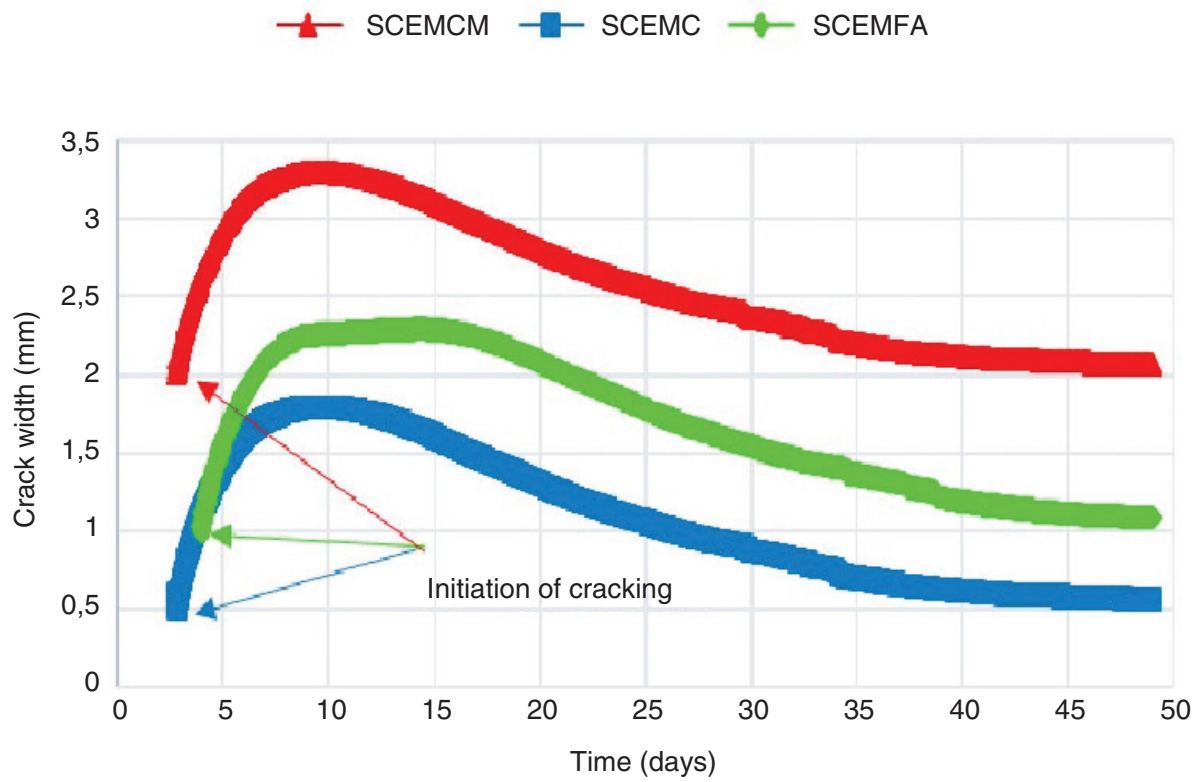

FIGURE 16. Measuring crack widths using a crack sensor.

whereas a paste of $100 \%$ of cement was in normal consistency with an E / C equal to 0.26. (67), in addition to the great finesse of this mud which explained the high demand for water for this mud and therefore a high bound water content leading to the risk of an early crack. We suggest a setting retarder to reduce the risk of cracking. Ongoing studies, such as capillary absorption, ATG and XRD analysis, SEM observations that corroborate these results.

\section{CONCLUSION}

This study makes a useful contribution to the formulation and characterization of more environmentally friendly concrete equivalent mortars that are based on the use of mineral additions in substitution for Portland cement. Two different mineral additions were considered, namely calcined mud (CM) and fly ash (FA).

Three SCEMs were formulated, a reference (control) mortar and two mortars containing $22 \%$ mineral additions, with a ratio $\mathrm{W} / \mathrm{B}=0.47$.

The effects of the type of binder used on the kinetics of development of strengths (compressive, flexural) at 28 days, free shrinkage, and cracking tendency using the ring test were quantified. The bound and free water content and the porosity accessible to water were evaluated as well.

- The results of the study of the behavior of fresh concrete equivalent mortar show the possibility of formulating mortars with calcined mud and fly ash, which can be characterized as self-compacting mortars.
- The 28-day compressive strength of the calcined mud mortar is greater than that of the fly ash mortar. Indeed, the eventual pozzolanic reaction of calcined mud may well be the cause, with the physical effect of this mud which its fineness is quite high and its activity index which is close to 1 . These findings are contrary to those obtained for flexural strengths at 28 days.

- After 100 days of drying, the fly ash mortar displayed the best free shrinkage results by decreasing the amplitude of autogenous, total and drying shrinkage. The compactness of the microstructure and the improvement of pore refinement led to a decrease in permeability and prevented the diffusion of water, and therefore decreased the desiccation shrinkage. These results are similar to those found in the literature. Calcined mud-based mortar develops deformations, due to shrinkage under autogenous conditions, similar to those of the control mortar and fly ash mortar; however, it remains the most sensitive mortar with regard to total shrinkage and drying shrinkage. These last two conditions are directly related to the age at which cracking occurs.

- In the case of restrained shrinkage, a crack was observed on the SCEMs, at different ages, depending on the mineral additions used. The crack was observed, on the same day and at close times, first on the SCEMCM and on the SCEMC, then on the SCEMFA. The crack width on mortars containing the mineral additions is greater than the one on the reference mortar. The presence of heat-treated mud in 
self-compacting concrete equivalent mortars seems to increase the risk of earlier cracking as compared to mortars containing fly ash. This is due to its lower flexural strength, also it is due to its higher drying shrinkage and low autogenous shrinkage. In fact, the increase in drying shrinkage leads to a decrease in the age of cracking so the reduction in drying shrinkage reduces the risk of cracking. However, the good correlation between free shrinkage and age of cracking should be analyzed carefully (68). While the $\mathrm{XRD}$, thermogravimetric and microstructural analysis allow us to provide explanations.

- However, the opening of the crack in the control concrete equivalent mortar is at least 1,2 and 1,3 times lower than that of SCEMFA and SCEMCM, respectively. Therefore, it can be concluded that the crack width is directly proportional to the porosity of the material and the amount of free water, while the age at which cracking occurs is inversely proportional to the amount of bound water.

- The partial replacement of Portland cement by fly ash did not decrease the $\mathrm{CO} 2$ content, on the contrary the porosity accessible to water and the total (bound and free) water content diminished.

Overall, the mortar with treated mud exhibited comparable behaviors towards autogenous shrinkage and early cracking to those of the control mortar. This substitution of cement with mud shows a real economic, environmental and technological advantage.

\section{ACKNOWLEDGMENTS}

The authors would like to thank Dr. Siham Kamali- Bernard from INSA University for his valuable advice and Mr. Christian Garand for his assistance in the measures of the restrained shrinkage and Mr. Jean-Luc Métayer for his help in the laboratory (LGCGM).

\section{REFERENCES}

1. Seklaoui-oukid, O. (2016). Valorization of the sediments of the Elmer Dja sidi Abed dam: a technical and economic study. Ph.D. thesis, (in French). Mouloud Mammeri University of Tizi-Ouzou, https://dl.ummto.dz/handle/ ummto/1228

2. National Agency of Dams in Algeria, mail@venturesonsite.com

3. Kazi aoual-benslafa, F.; Maarouf, H.; Semcha, A.; Mekerta, B. (2011) Durability of mortars based on dredged sediments from the port of Oran, (in French). Mediterranean Coastal and Maritime Conference Edition 2, Tangier, Morocco. http://www.paralia.fr. https:// doi.org/10.5150/cmcm.2011.042

4. Itim, A.; Ezziane, K.; Kadri, E. (2010) Study of shrinkage deformations of a mortar containing different mineral additions, (in French) International Symposium on Construction in Seismic Zone Hassiba Benbouali University of Chlef (Algeria).

5. Acker, P. (1988) Mechanical Behavior of Concrete: Contributions of the Physico-Chemical Approach, (in French). LPC. Res. Report, No. 152, 122.

6. Wild, S.; Khatib, J.M.; Roose, L.J. (1998). Chemical shrinkage and autogenous shrinkage of Portland cement metakaolin pastes. Advan. cem. Res. 10. https://doi.org/ 10.1680/adcr.1998.10.3.109

7. Benkaddour, M.; Kazi aoual, F.; Semcha, A. (2009) Durability of mortars based on natural pozzolan and artificial pozzolan, (in French). Natur. Techno. Rev. N${ }^{\circ} 01$. 63-73.

8. Boukendakdji, O.; Kadri, E.; Kenai, S. (2012). Effects of granulated blast furnace slag and superplasticizer type on the fresh properties and compressive strength of self-compacting concrete. Cem. Concr. Compos. 34(4), 583-590. https://doi.org/10.1016/j.cemconcomp.2011.08.013

9. Naik, T. R.; Kumar, R.; Ramme, B. W.; Canpolat, F. (2012). Development of high-strength, economical self-consolidating concrete. Construcc. Build. Mater. 30, 463-469. https:// doi.org/10.1016/j.conbuildmat.2011.12.025

10. Türkel, S.; and Kandemir, A. (2010). Fresh and hardened properties of SCC made with different aggregate and mineral admixtures. J. Mater. Civ. Eng. https://doi.org/10.1061/ (ASCE)MT.1943-5533.0000107

11. Ayed, K.; Benaissa, A.; Vidal, T.; Pons, G. (2011) Study of the shrinkage and creep of self-compacting concretes based on natural pozzolans and Algerian siliceous fines, (in French). Can. Rev. civ eng. 39. https://doi.org/10.1139/ 111-116

12. Bouhamou, N. (2008) Influence of composition parameters on the behavior of self-compacting concrete with respect to the shrinkage, Doctoral thesis, (in French). University of Mostaganem. https://doi.org/10.1139/L09-071

13. Bouhamou, N.; Belas, N.; Bendani, K.; Mebrouki, A. (2013). Shrinkage behavior of a self-compacting concrete. Mater. Techno. https://www.researchgate.net/publication/ 292922884

14. Bouhamou, N.; Mostefa, F; Mebrouki, A.; Belaribi, N.; Mesbah, A.H. (2014) Study of the behavior of a selfcompacting concrete based on dredged mud with respect to shrinkage (in French). Colloquium 01 Eco materials. https://www.researchgate.net/publication/282055518

15. Taieb, F.; Belas, N.; Belaribi, O.; Belguesmia, K.; Hadj Sadok, R. (2018). Influence of calcined mud on the mechanical properties and shrinkage of self-compacting concrete. $2^{\text {nd }}$ International Congress on Materials and Structural Stability (CMSS-2017). https://doi.org/10.1051/ matecconf/201814901026

16. Jianyong, L.; Yan, Y. (2001). A study on creep and drying shrinkage of high-performance concrete. Cem. Concr. Res. 31(8), 1203-1206. https://doi.org/10.1016/ S0008-8846(01)00539-7

17. Jin, X.; and Li, Z. (2003). Effect of mineral admixture on properties of young concrete. J. Mater. Civ. Eng. 15, 5(435), 435-442. https://doi.org/10.1061/(ASCE) 0899-1561(2003)15:5(435)

18. Niknezhad, D.; Kamali-Bernard, S.; Mesbah, H-A. (2017). Self-Compacting Concretes with Supplementary Cementitious Materials: Shrinkage and Cracking Tendency. Amer. Soc. Civ. Eng. https://doi.org/10.1061/ (ASCE)MT.1943-5533.0001852

19. Gleize, P J.P. Cyr M. Escadeillas, G. (2007). Effects of metakaolin on autogenous shrinkage of cement pastes. Cem \& Concr. Com 29, 80-87. https://doi.org/10.1016/j. cemconcomp.2006.09.005

20. Ogawa, A.; Sakata, K.; Tanaka. S (1995). A study on reducing shrinkage of high- flowable concrete, 2 nd international symposium of CANMET/ACI.P. 55-72. Las Vegas, Etats-Unis.

21. Rols, S.; Ambroise, J.; Pera, J. (1997). Development of an admixture for Sel-leveling concrete. Proceedings of the 5 th CANMET/ACI International Conference on Superplastifiant and the chemical admixtures in concrete. P493-509. V.M. Malbotra Rome, Italie. 
22. Tanaka, K.; Sato, K.; Watanabe, S.; Arina, I.; Suenaga, K. (1993). Development and utilization of high-performance concrete for the construction of the Akashi Kaikyo Bridge. International Symposium on high Performance Concrete in Science Environments. 25-51. SP 140ACI, Detroit, Etats-Unis

23. Persson, B.;(2001) A comparison between mechanical properties of Self-Compacting Concrete and the corresponding properties of normal Concrete. Cem. Concr. Res. 31(2). 193-198. https://doi.org/10.1016/S0008-8846(00)00497-X

24. Turcry, P.; Loukili, A. (2006). Evaluation of plastic shrinkage cracking of self -compacting concrete. ACI. Mater. $j$. 103, 272-279. https://doi.org/10.14359/16611

25. Fernández-Gómez, J.; Lands Berger, GA. (2007) Evaluation of shrinkage prediction models for self-consolidating concrete. ACI. Mater. J. 104, 5, p. 464-473.

26. Roziere, E.; Granger, S.; Turcry, P.; Loukili, A. (2007). Influence of paste volume on shrinkage cracking and fracture properties of Self-Compacting concrete. Cem. Concr. Compo. 29(8), 26-636. https://doi.org/10.1016/j. cemconcomp.2007.03.010

27. Persson, B. (2005). Creep of Self -compacting CONCREEY Creep, Shrinkage and Durability of Concrete and concrete structures. 535-540. Nantes.

28. Mazzotti, C.; Savola, M.; Ceccoli, C. (2005). A comparison between long term proprieties of self -compacting concretes and normal vibrated concretes with same strength CONCREEP7 Creep, shrinkage and durability of concrete and concrete structures. 7, 523-528. ISTE.

29. Heirman, G.; Vandewalle, L.; Gemert, D. van; Bouel, V.; Audenaert, k.; Schutter, G. de; Desmet, B.; Vantomme, j. (2008) Time dependent deformations of limestone powder self- compacting concrete Eng. Struc. 30(10), 2945-2956. https://doi.org/10.1016/j.engstruct.2008.04.009

30. Chopin, D.; Francy, O.; Lebourgeois, S.; Rougeau, P. (2003). Creep and shrinkage of heat-cured Self compacting concrete (SCC) $3^{\text {rd }}$ international RILEM Symposium Self- compacting concrete. 672-683, Reykjavik, Island.

31. Loukili, A. (2010) Self-Compacting concretes, Lavoisier éditions, Cachan, (in French).

32. Shah, S. P.; Ouyang, C.; Marikunte, S.; Yang, W.; BecqGiraudon, E. (1998). A method to predict shrinkage cracking of concrete. ACI. Mater. J. 95 (4), 339-346.

33. Hammer, T. A. (2003). Cracking susceptibility due to volume changes of self-compacting concrete. Proc. 3rd Int. RILEM Symp. on Self Compacting Concrete, Reykjavik, Iceland, 553-557.

34. Turcry, P.; Loukili, A.; Haidar, K.; Pijaudier-Cabot, G.; Belarbi, A. (2006). Cracking Tendency of Self-Compacting Concrete Subjected to Restrained Shrinkage: Experimental Study and Modelling. J. Mater. Civ. Eng. 18 (1), 46-54. https://doi.org/10.1061/(ASCE)0899-1561(2006)18:1(46)

35. Samouh, H. (2015). Evaluation of the sensitivity to cracking of SCCs: Contribution of viscerelastic behavior analysis, Young Researchers Award René Houpert. ISABTP / UPPA, Anglet, 27 to 29. hal-01167660, (in French).

36. Bentur, A. (2002), Early age cracking tests. RILEM state of the art report-early age cracking in cementitious systems.

37. Bentur, A.; Kovler, K. (2003). Evaluation of early age cracking characteristics in cementitious systems. Mater. Struc. 36,183-190. https://doi.org/10.1007/BF02479556

38. Siad, H. (2010) Influence of the type of mineral addition on the physical-mechanical behavior and durability of selfcompacting concrete. PhD thesis, (in French) National Institute of Applied Sciences of Rennes.

39. Semcha, A. (2006) Valorization of dredged sediments: Applications in the construction sector, the case of the Fergoug dam, doctoral thesis, (in French) University of Reims Champagne-Ardenne. http://www.theses.fr/ 2006REIMS023/document

40. Mesbah, H.; Laraba, A.; Yahia, A. (2016). Flowability and Stability Performance of Self-Consolidating Concrete in Full-Scale Beam , 8th International RILEM Symposium on Self-Compacting Concrete, Washington, DC, United States. Conference Proceedings, 665-674. https://hal. archives-ouvertes.fr/hal-01636911
41. Güneyisi, E.; Gesoğlu, M. (2008). Properties of self-compacting mortars with binary and ternary cementitious blends of fly ash and metakaolin. Mater. Struc. 41:1519-1531. https://doi.org/10.1617/s11527-0079345-7

42. FNARC (2002). Specification and guidelines for selfcompacting concrete. 29-35. Free pdf copy downloadable from. http://www.efnarc.org

43. Niknezhad, D. (2015) Contribution to the study of mechanical behavior, shrinkage and transport properties of selfcompacting concretes with mineral additions, numerical and experimental approach, $\mathrm{PhD}$ thesis, (in French). INSA Rennes. http://www.theses.fr/2015ISAR0035

44. Techniques and Methods of Road and Bridge Laboratories, microstructural characteristics and properties related to the durability of concretes. Methods of measurement and laboratory testing. Test Methods No. 58, (2002).

45. ASTM C.1581, (2004). Standard Test Method for Determining Age at Cracking and Induced Tensile Stress Characteristics of Mortar and Concrete under Restrained Shrinkage.

46. Mesbah, H. A.; Buyle-Bodin, F. (1999). Efficiency of polypropylene and metallic fibres on control of shrinkage and cracking of recycled aggregate mortars. Construcc. Build. Mater. 13(8), 439-447. https://doi.org/10.1016/ S0950-0618(99)00047-1

47. Niknezhad, D.; Kamali-Bernard, S. (2015) Study of the shrinkage and transport properties of Eco-SCCs based on mineral additions. 33rd Meeting of the AUGC, (in French). ISABTP / UPPA, Anglet, 27 to 29. hal-01167619. https://www.researchgate.net/publication/277456556

48. Bernardini, C. (2011) Self-compacting concrete, Press Bridges and Pavements, Paris, (in French).

49. Jiang, S.; Vandamme, H. (1996). Influence of fillers of different types on the hydration and texture of $\mathrm{C}_{3} \mathrm{~S}$ pastes, CRMD-ATILH report, University of Orleans.

50. Belaribi, O. (2015) Durability of self-compacting concrete based on mud and pozzolan, PhD Thesis, (in French). Cergy-Pontoise University and University of Mostaganem.

51. Sabir, B.B; Wild, S; Bai, J. (2001). Metakaolin and calcined clays as pozzolans for concrete. Cem. Concr. Compo. 23(6): 441-454. https://doi.org/10.1016/S0958-9465(00)00092-5.

52. Belas, N.; Besseghier, N.; Mebrouki, A.; Bouhamou N. (2009) Towards an environmental protection by valuing the dredged mud of the dam as a component of concrete, (in French) Mater. Techni. 97, 231-240. https://doi. org/10.1051/mattech/2009039

53. Neville, A. M. (1996). Properties of concrete, 4th Ed., Addison Wesley Longman, London.

54. Gendron, F; Turcry, P.; Ait-Mokhtar, A. (2017). Coefficient of diffusion of $\mathrm{CO}_{2}$ from cement pastes - experimental study of the influence of the nature of the binder and accelerated carbonation, 23rd French Congress of Mechanics, Lille, August 28th to September $1^{\text {st }}$. http://hdl. handle.net/2042/63471

55. Audenaert, K.; Boel, V.; Schutter, G. de (2007). Chloride migration in self-compacting concrete, Proceedings of the 5th International Conference on Concrete under Severe Conditions Environment and Loading CONSEC'07 Tours, France, 291-298.

56. Ollivier, J.; Torrenti, J. (2008). The porous structure of concrete and transfer properties, Chapter. https://www. researchgate.net/publication/290158099.

57. Mehta, P.K. (1987) Natural pouzzolans, in, Complementary materials in cementation, (in French). Editor V.M. Malhortra. 3-38.

58. Schwartzentruber, L.; Torrenti, J. (2014) The big book of concretes, (in French) Editions Monitor, Paris.

59. José Oliveira, M. (2017). Shrinkage of self-compacting concrete. A comparative analysis CEPAC, University of the Algarve, Faro, Portugal, J. Build. Eng. 9, 117-124. https://doi.org/10.1016/j.jobe.2016.12.002.

60. Atis, C.D.; Kilic, A.; Sevim, U.K. (2004). Strength and shrinkage properties of mortar containing a nonstandard high calcium fly ash. Cem. Concr. Res. 34, Nº1, 99-102. https://doi.org/10.1016/S0008-8846(03)00247-3 
61. Chindaprasirt, P.; Homwuttiwong, S.; Sirivivatnanon, V. (2004). Influence of fly ash fineness on strength, drying shrinkage and sulphate resistance of blended cement mortar. Cem. Concr. Res. 34, Nº , 1087-1092. https://doi. org/10.1016/j.cemconres.2003.11.021

62. ACI Committee 232, Use of fly ash in concrete, Manual of concrete practice, ACI 232.2R-96, 33.

63. Mehta P.K. (1989). Pozzolanic and cementitious byproduts in concrete: Another look, Proceedings of the 3th CANMET/ACI International Conference on fly ash, silica fume, slag and natural pozzolans in concrete, Trondheim, Norway, 1-43.

64. Mesbah, H. (1997) Improvement of the behavior of mortars based on recycled aggregates by addition of fibers, PhD Thesis, (in French). University of Artois. http://www. theses.fr/1997ARTO0003/id
65. Grzybowski, M.; Shah, S. P. (1990). Shrinkage cracking of fiber reinforced concrete. ACI. Mater. J. 87(2), 138-148. https://doi.org/10.14359/1951

66. Samouh, H.; Rozière, E.; Loukili, A. (2012) Interpretation of the measures of drying shrinkage of self-compacting concrete (SCC), (in French). XXX ${ }^{\mathrm{e}}$ AUGC-IBPSA Meeting Chambéry, Savoie. https://doi.org/10.13140/2.1.1348.3044

67. Belguesmia, K.; Belas Belaribi, N.; Amiri, O.; Leklou, N.; Belaribi, O. (2018). Influence of treated sediment substitution percentage on workability, strength and porosity of SCC. J. Mater. Eng. Struc. 5, 47-55

68. Rozière, E.; Granger, S.; Turcry, Ph.; Loukili, A. (2007). Influence of paste volume on shrinkage cracking and fracture properties of self-compacting concrete. $\mathrm{Cem}$. Concr. Compo. 29(8): 626-636. https://doi.org/10.1016/j. cemconcomp.2007.03.010 